\title{
Manajemen nasehat nutrisi dalam praktek dokter gigi Management of nutrition advised in dentist practice
}

\author{
Rosa Amalia \\ Bagian Ilmu Kedokteran Gigi Pencegahan dan Ilmu Kedokteran Gigi Masyarakat \\ Fakultas Kedokteran Gigi Universitas Gadjah Mada \\ Yogyakarta, Indonesia
}

\begin{abstract}
The evidence of relation between nutrition and oral health has addressed nutrition issues on a new urgency in dental practices as a part of efforts in developing quality of care. Nutrition is a modifiable factors and could be adviced to patients that ensure progression and maintainance of oral health status. Dietary advice to patients should be positive and personalized if possible and can be in line with general health. This paper is intended to provide an overview of management of dietary advice for patients with dental caries, periodontal disease and oral surgery which could be implemented in dental practice setting. The appropriate and specified nutrition advice can help patient recover from dental disease and achieved the best result of dental treatment and prevention.

Keywords: diet, nutrition, prevention, clinical setting
\end{abstract}

\begin{abstract}
ABSTRAK
Nutrisi merupakan salah satu bagian penting peningkatan mutu pelayanan kesehatan dalam praktek dokter gigi. Nutrisi merupakan faktor yang dapat dimodifikasi dan dapat diberikan pada pasien secara personal untuk meningkatkan dan menjaga status kesehatan gigi dan mulut. Tujuan penulisan artikel ini adalah membahas manajemen nasehat nutrisi untuk pasien dengan keluhan karies, penyakit periodontal dan pasien pasca bedah mulut pada praktek dokter gigi. Penerapan nasehat nutrisi yang tepat dapat membantu pasien untuk sembuh dari penyakit gigi dan mulut dan mendapatkan hasil perawatan serta pencegahan penyakit yang lebih memuaskan.
\end{abstract}

Kata kunci: diet, nutrisi, pencegahan, praktek

Koresponden: Rosa Amalia, Bagian Ilmu Kedokteran Gigi Pencegahan dan Ilmu Kedokteran Gigi Masyarakat, Fakultas Kedokteran Gigi Universitas Gadjah Mada, Jalan Denta Sekip Utara Yogyakarta 55581, Indonesia. Tel: +62 81578804082, Fax: +62 274515307, E-mail: rosadewanto@yahoo.com

\section{PENDAHULUAN}

Nutrisi memiliki peran yang penting pada etiologi berbagai penyakit sehingga pemahaman akan fungsi dan peran nutrisi dapat menjadi pendukung dalam perawatan klinis yang diberikan dokter gigi. ${ }^{1}$ Adanya keterbatasan pada desain intervensi nutrisi yang efektif pada praktek dokter gigi menyebabkan nutrisi belum menjadi bagian integral pada perawatan pasien..$^{2-3}$ Dokter gigi perlu memahami peran nasehat nutrisi pada pasien untuk diterapkan dalam praktek untuk mendukung pasien menjalankan pola makan yang lebih sehat.

Pemahaman tentang pola makan dapat menjadi dasar penetapan tujuan perawatan, prioritas dan penjadwalan nasehat nutrisi yang perlu diberikan pada pasien. Nasehat nutrisi untuk pasien perlu diberikan dengan mempertimbangkan pula kondisi kesehatan sistemik pasien sehingga tidak menimbulkan dampak yang kontradiktif. ${ }^{4-5}$ Penilaian pola makan dapat juga menunjukkan perilaku pasien yang berpotensi mempengaruhi kesehatan gigi dan mulut, yang selanjutnya dapat menjadi pertimbangan dalam membuat keputusan klinis yang dibuat dalam praktek dokter gigi.
Penyakit gigi dan mulut yang banyak ditemukan dalam masyarakat saat ini adalah karies dan penyakit periodontal. ${ }^{6}$ Selain itu, penanganan pasien pasca bedah mulut juga menjadi masalah yang umum dihadapi oleh dokter gigi. ${ }^{7}$ Adanya kebutuhan untuk mengurangi risiko terjadinya penyakit dan keberhasilan perawatan memerlukan pemahaman tentang pentingnya manajemen nutrisi sebagai bagian integral dari praktek dokter gigi. Tujuan dari penulisan artikel ini adalah membahas manajemen nasehat nutrisi sebagai upaya pencegahan beberapa penyakit gigi dan mulut serta langkah-langkah yang dilakukan untuk mendukung keberhasilan perawatan pada pasien.

\section{TINJAUAN PUSTAKA}

\section{Tahap konseling nutrisi}

Nutrisi dibutuhkan pada setiap tahap kehidupan manusia untuk mencukupi kebutuhan energi tubuh. Kecukupan nutrisi dalam tubuh dipengaruhi oleh cara mengkonsumsi, jenis dan waktu pemberian makanan, yang kesemuanya akan berpengaruh pada kesehatan gigi dan mulut. ${ }^{8}$ Teknik penilaian nutrisi diperlukan untuk 
menentukan kebutuhan pasien secara perseorangan karena pasien memiliki perbedaan pada kondisi kesehatan, kebutuhan nutrisi, preferensi jenis makanan dan bereaksi secara berbeda pada perawatan medis. ${ }^{9}$ Penilaian diet secara ideal harus memberikan gambaran nyata tentang kebiasaan makan, dapat diterima pasien dan memiliki dampak biaya yang rendah. Secara umum, langkah awal konseling nutrisi yang komprehensif dan sistematis untuk pasien yang dapat dilakukan dalam praktek dokter dengan beberapa tahap. ${ }^{10}$

Tahap pertama adalah mengidentifikasi pasien yang memiliki risiko tinggi penyakit gigi dan mulut berkaitan dengan kondisi sosial ekonomi, umur, geografis, gaya hidup dan sebagainya. Langkah kedua adalah membuat sejarah pola makan atau yang disebut dietary history. Langkah yang dimaksud disini bukan penilaian yang bersifat komplek dan membutuhkan ketrampilan tinggi tetapi lebih untuk mendapatkan informasi pola makan pasien sehari-sehari. Informasi paling baik diperoleh melalui catatan makan (food diary) yang dilakukan oleh pasien paling tidak selama 3 hari. Food diary paling baik ditulis pada akhir minggu dengan menuliskan waktu saat makan atau minum dan tempatnya, yaitu di rumah atau di luar rumah, deskripsi jenis makanan, jumlah asupan dan kapan waktu tidur. Pasien harus dimotivasi dan diinformasikan dengan jelas tujuan dari aktivitas ini. Dokter gigi perlu memberikan instruksi yang tepat tentang cara melakukan catatan makanan baik secara verbal maupun format tulisan dan pasien diberikan kesempatan untuk bertanya. Langkah ketiga adalah menetapkan tujuan nasehat nutrisi. Pengurangan jumlah dan jenis makanan yang tidak sehat menjadi tujuan utama dalam pemberian nasehat nutrisi. Tujuan yang realistis, tepat dan terukur adalah hal yang utama.

Program yang bertahap akan memiliki tingkat keberhasilan yang lebih tinggi daripada yang bersifat radikal. Langkah selanjutnya adalah membuat perencanaan pola makan pasien. Makan adalah kegiatan sosial yang dipengaruhi oleh banyak faktor. Perencanaan pola makan yang sehat untuk pasien merupakan hal yang penting sebagai panduan baik untuk pasien sendiri maupun keluarganya sebagai orang terdekat yang akan memberikan dukungan. Intervensi diet yang diberikan harus disesuaikan dengan kondisi dan kebutuhan individual pasien. ${ }^{11}$ Pada berbagai tahap konseling nutrisi, pasien membutuhkan dukungan dan umpan balik dari dokter gigi untuk mempertahankan kebiasaan makan yang baik. Monitoring dan review yang terus menerus diperlukan untuk mempertahankan motivasi pasien. Setelah perencanaan disetujui oleh pasien maka penilaian kemajuan pasien perlu dilakukan sekitar satu atau dua minggu kemudian. Jika pasien masih dalam suatu perawatan dental maka kemajuan mereka dapat secara singkat dinilai pada setelah perawatan klinis selesai.

Rujukan pada profesi lain yang lebih kompeten dapat dilakukan apabila pasien memiliki gejala pada gigi dan mulut dengan kondisi masalah gizi tertentu di luar kemampuan seorang dokter gigi. Rujukan ke ahli gizi untuk perawatan lebih lanjut dapat diberikan pada pasien tertentu, misalnya pada individu dengan masalah kesehatan khusus atau pasien yang memiliki pola makan ekstrim seperti anorexia atau bulimia. Pengetahuan dokter gigi untuk mengenali ciri pasien dengan kondisi khusus tersebut sangat diperlukan untuk mencegah kesalahan dalam memberikan nasehat nutrisi.

\section{Karies}

Karies merupakan penyakit yang dapat dicegah dan dapat dikontrol. Etiologi karies secara ilmiah sudah diketahui yaitu disebabkan oleh bakteri dalam mulut yang mengalami metabolisme aktif karena adanya zat gizi yang bersifat kariogenik pada permukaan gigi. ${ }^{12}$ Karies dikenal sebagai penyakit yang dipengaruhi oleh hal yang bersifat psikologis, ekonomi, budaya dan geografi yang dapat mempengaruhi kebiasaan makan, insidensi dan perkembangan karies. ${ }^{13-14}$ Pengaruh ini berbeda-beda pada diri seseorang sehingga dibutuhkan nasehat gizi yang disesuaikan dengan masing-masing pasien. Pasien yang secara khusus perlu mendapatkan konseling nutrisi untuk pencegahan penyakit karies adalah pasien yang memiliki pola makan yang tidak sehat, pasien dengan rampan karies, memakai orthodontic band atau alat lain yang bersifat retentif pada makanan kariogenik serta pasien yang memiliki motivasi tinggi untuk tindakan pencegahan penyakit gigi dan mulut. ${ }^{15}$

Pembuatan dietary history dilakukan dengan meminta pasien mencatat secara lengkap apa saja yang dimakan pasien termasuk minuman dan makanan ringan. Pada prosedur ini, food diary dibuat selama lima hari untuk mendapatkan gambaran lengkap pola makan pasien. Food diary diisi oleh pasien dengan mencatat makanan atau minuman yang dimakan secara detail dimulai dari makan pagi, makan siang dan makan malam 
termasuk makanan ringan seperti permen atau snack. Keterangan frekuensi makanan, takaran, jenis makanan dan cara memasak, penggunaan gula, sirup, susu atau sereal ditambahkan sebagai informasi pelengkap.

Food diary pasien yang telah terisi lengkap digunakan sebagai acuan dokter gigi untuk memberikan konseling nutrisi dengan menandai macam, jumlah dan cara penyajian yang tidak sesuai dan harus dihilangkan dari pola makan pasien sehari-hari. Saat evaluasi dietary history, pasien dapat diminta untuk mengingat kapan mulai merasakan adanya gangguan karies dan selanjutnya mengevaluasi jenis makanan apa saja yang kariogenik dengan memberikan tanda pada catatan. Dokter gigi sebagai konselor perlu untuk selalu memberikan konseling yang bersifat positif dan konstruktif. Pasien harus terlibat aktif dalam peningkatan pola makan sehat dan mendeteksi makanan apa saja yang bersifat kariogenik dan membentuk plak. Perubahan radikal pola makan perlu dihindari karena kemungkinan besar akan ditolak oleh pasien.

Pada perencanaan intervensi yang perlu diperhatikan untuk pencegahan atau kontrol karies adalah membatasi jumlah periode makan menjadi tiga kali sehari dengan penekanan untuk mengurangi atau menghilangkan memakan makanan ringan diantara waktu makan. Peningkatkan intake dari makanan protektif seperti daging, susu dan ikan yang mengandung protein dan fosfat perlu dilakukan diiringi dengan menurunkan penggunaan karbohidrat (sekitar 30\%-50\% total kalori), eliminasi makanan manis yang lengket serta memperbanyak makan buah dan sayuran segar. ${ }^{16}$

\section{Penyakit periodontal}

Sebagian besar penyakit periodontal disebabkan oleh faktor iritatif lokal seperti dental plak, kalkulus, material alba, food impaction, restorasi yang tidak benar, disharmoni oklusal dan kondisi ekstrim mekanis, kimia dan termal. ${ }^{17}$ Prosedur yang perlu dilakukan pada pasien ini dimulai dengan mengidentifikasi gaya hidup pasien sehari-hari, mengevaluasi makanan yang potensial menyebabkan pembentukan plak, mengevaluasi kecukupan diet pasien, menilai kondisi sistemis yang mungkin ada dan menguji adanya tanda klinis malnutrisi. Pada kondisi tertentu tes laboratoris bisa diperlukan untuk mengatahui kadar vitamin $\mathrm{C}$ dalam darah. ${ }^{18}$

Untuk kepentingan dietary history, pasien diminta untuk membuat food diary selama 5 hari dengan instruksi yang sama seperti pada pencegahan karies di atas. Setelah catatan makanan diberikan oleh pasien, dokter gigi dapat melakukan evaluasi dengan cara menunjukkan pada pasien makanan mana saja yang kurang, misalnya susu dan sayur-buah untuk meningkatkan kecukupan diet dengan memberikan penekanan pada makanan yang berguna untuk kesehatan jaringan periodontal. Hal lain yang perlu diperhatikan adalah komposisi dan konsistensi dari makanan dan pasien diminta untuk menghilangkan makanan manis dan diganti dengan makanan sehat. Makanan sehat yang perlu dianjurkan untuk pasien diantaranya adalah protein untuk mencegah inflamasi dan degenerasi, asam askorbat untuk mencegah kerusakan sel dan menjaga integritas mukosa rongga mulut, vitamin A untuk pembentukan sel baru, vitamin D, kalsium dan fosfor untuk pembentukan tulang, serta vitamin B kompleks yang berfungsi pada pembentukan dan pemeliharaan jaringan pada masa penyembuhan. ${ }^{19}$

\section{Pasien oral surgery}

Nasehat gizi yang memadai perlu diberikan pada pasien pasca bedah mulut supaya sembuh lebih cepat dan memberikan perasaan akan kondisi fisik dan emosional yang sehat. Pada kondisi ini pasien biasanya merasakan stres dan memiliki kesulitan mengunyah sehingga diperlukan nasehat gizi yang tepat. Keseimbangan nutrisi yang tepat dipilih berdasarkan kandungan gizi yang berperan pada penyembuhan luka dan ketahanan terhadap infeksi.

Makanan yang diperlukan dalam proses penyembuhan pasien, diantaranya adalah protein, karbohidrat, lemak, vitamin, mineral, dan air. Fungsi protein adalah penyedia asam amino untuk pembentukan dan pemeliharaan jaringan. Kecukupan protein menjamin adanya kecukupan jumlah sel dan volume darah, enzim, antibodi dan antigen untuk metabolisme dan fungsi tubuh yang diperlukan oleh pasien bedah karena rata-rata pemenuhan kebutuhan harian pasien pasca bedah adalah dua kali rata-rata kebutuhan normal. Pada kondisi ini, protein dari hewani lebih diutamakan daripada nabati. Pasien pasca bedah mungkin mengalami demam dan memiliki basal metabolic rate yang meningkat sehingga membutuhkan tambahan kalori. Kecukupan kalori dari karbohidrat dan lemak diutamakan karena protein lebih diutamakan untuk perbaikan jaringan. Karbohidrat diutamakan karena lebih mudah dicerna dan segera digunakan di dalam tubuh 
daripada lemak. Pada kondisi pasca bedah, kebutuhan vitamin B kompleks sebagai koenzim untuk penyembuhan perlu diperhatikan karena banyak terbuang melalui darah atau cairan karena sifatnya yang larut dalam air, sedangkan vitamin C mutlak diperlukan pada 15 hari pasca bedah yang berfungsi penting untuk pembentukan kolagen. Untuk mengganti cairan yang terbuang selama pembedahan, pasien perlu mendapatkan air minum dengan elektrolit (potasium, sodium dan klorida) sebanyak 2 liter atau 8 gelas per hari. Elektrolit dapat dicukupi dengan penambahan garam pada makanan atau dengan isotonic saline solution. ${ }^{20}$

Pasien dengan kasus pembedahan tidak membutuhkan catatan harian makanan untuk evaluasi, kecuali pada kondisi tertentu seperti anemia, alkoholisme, diabetes atau malnutrisi. Pada keadaan ini, jika merupakan pembedahan prosedur elektif maka sebisa mungkin ditunda sampai pasien memiliki status gizi yang optimal. Jika pasien mengalami malnutrisi maka diet tinggi protein dengan kecukupan karbohidrat dan lemak yang memenuhi kebutuhan kalori 2500 per hari dapat diberkan selama tujuh sampai empat belas hari sebelum tindakan bedah dilakukan. ${ }^{21}$

Pada akhirnya pemberian nasehat gizi untuk pasien akan efektif apabila melibatkan tim dalam praktek. ${ }^{22} \mathrm{Hal}$ ini penting karena biasanya dokter gigi memiliki kesibukan dalam menangani masalah klinis pasien. Dalam kerja tim, peran utama dokter gigi adalah mengidentifikasi pasien yang memerlukan nasehat gizi dan mengkoordinasi kegiatan selanjutnya. Dokter gigi memiliki tanggung jawab profesional untuk menilai sifat dari masalah yang dihadapi pasien dan apa saja yang diperlukan. Delegasi pada perawat gigi yang terlatih dengan merencanakan intervensi gizi dapat dilakukan selanjutnya. Untuk keberhasilan perawatan, dokter gigi harus memonitor kemajuan pasien dan melakukan review secara langsung pada waktu tertentu.

\section{PEMBAHASAN}

Pemberian nasehat dan intervensi nutrisi pada pasien telah diterima dan diakui manfaatnya dalam praktek medis kedokteran gigi. Hal tersebut sejalan dengan hasil studi yang telah dilakukan, yaitu intervensi nutrisi memiliki tingkat keberhasilan yang tinggi untuk mencegah berkembangnya penyakit gigi. ${ }^{23}$ Tahapan yang sederhana dari konseling dan intervensi nutrisi memungkinkan dokter gigi untuk mengikuti prosedur dengan mudah.
Walaupun demikian, informasi tentang metode intervensi ini masih sangat terbatas sehingga dokter gigi perlu mempelajari metode tersebut baik dari pustaka ataupun mendiskusikan dengan pihak yang lebih kompeten. Selain itu, pemberian konseling yang diikuti dengan intervensi nutrisi memiliki keterbatasan karena sangat bergantung pada kerja sama dengan pasien. Kontrol yang lemah dari dokter gigi menyebabkan pasien dapat dengan mudah kembali pada kebiasaan lama sehingga tujuan pencegahan tidak dapat tercapai. Pengaruh gaya hidup dan kemudahan akses pada makanan yang tinggi gula terutama pada anak-anak membutuhkan kedisiplinan tersendiri dari pasien. ${ }^{24-25}$ Dokter gigi harus dapat secara selektif memilih metode yang paling sesuai dengan kemampuan pasien untuk menerima intervensi yang diberikan. Pemilihan intervensi nutrisi akan lebih berhasil apabila pasien dan keluarganya terlibat secara aktif dalam menentukan pola makan sehat.

Dokter gigi perlu meningkatkan kegiatan konseling dan intervensi dalam praktek karena metode ini memiliki pengaruh tidak hanya untuk kesehatan gigi semata tetapi juga kesehatan umum secara keseluruhan. Konseling nutrisi memiliki dampak jangka panjang yang lebih postif untuk pasien daripada medikasi atau pengobatan yang hanya memiliki jangka pendek. Keterbatasan pengetahuan tentang metode intervensi yang tepat dapat diatasi dengan meningkatkan kolaborasi dengan profesi lain terkait seperti ahli teknologi pangan ataupun ahli gizi. Pengetahuan yang luas tentang faktor etiologi penyakit gigi dan mulut sangat diperlukan untuk menetapkan pola intervensi yang akan diberikan pada pasien. Hal yang tidak kalah penting adalah dokter gigi juga harus mengenali makanan yang ada di sekitarnya yang berpotensi sebagai faktor penyebab penyakit misalnya karies. Promosi aktif akan pentingnya makanan sehat diharapkan dapat memberikan kontribusi yang nyata bagi kesehatan masyarakat.

\section{SIMPULAN}

Pemberian nasehat gizi merupakan langkah penting yang dapat dilakukan dokter gigi untuk mencegah penyakit gigi dan mulut. Hal yang dapat dilakukan untuk menolong pasien merubah pola makan menjadi lebih baik adalah dengan melakukan penilaian pada diet history, menentukan tujuan yang tepat dan dapat dilaksanakan, serta membuat perencanaan makan. Kebutuhan nutrisi pada pasien dengan problem karies, periodontal dan pasca bedah dapat 
disesuaikan dengan kondisi masing-masing individu. Penyesuaian kebutuhan per individu dilakukan untuk memperoleh pengaruh yang lebih besar pada pola makan dan pada akhirnya meningkatkan kesehatan.

Secara keseluruhan dokter gigi memiliki tanggung jawab dan komitmen untuk pencegahan penyakit dan promosi kesehatan yang salah satunya adalah dengan mengevaluasi pemahaman pasien akan pola makan yang sehat dan menasehatkan hal yang terbaik. Evaluasi bertujuan untuk mengaplikasikan pola makan yang sehat secara realistis pada pasien, memberikan umpan balik dan nasehat nutrisi yang selanjutnya dapat meningkatkan kualitas kehidupan pasien secara umum

\section{DAFTAR PUSTAKA}

1. World Health Organization. Diet, nutrition and the prevention of chronic diseases : report of a joint WHO/FAO expert consultation. WHO technical report series 916. World Health Organization. Geneva, Switzerland. 2003.

2. Brown. Research in dental health education and health promotion: a review of the literature. Health Educ Q 1994; 21: 83-102.

3. König KG, Diet and oral health. Int Dent J 2000; 50: 162-74.

4. Jackson AA. Human nutrition in medical practice: The training of doctors. Proceeding of the Nutrition Society; Cambridge: Cambridge University Press 2001 (60): 257-63.

5. Webb GP. Nutrition: A health promotion approach. 3rd Ed. London: Hodder Arnold; 2008.

6. Departemen Kesehatan Republik Indonesia. Riset Kesehatan Dasar. Jakarta: Departemen Kesehatan Republik Indonesia; 2008.

7. BA Burt, Ismail Al, Morrison EC, Bettran ED. Risk factors for tooth loss over a 28 year period. J Dent Res 1990; 69(5): 1126-30.

8. Arisman. Gizi dalam daur kehidupan: Buku ajar ilmu gizi. Jakarta: EGC; 2004.

9. Whitney EN, Cataldo CB, Rolfes SR. Understanding normal and clinical nutrition. Scand J Food Nutr 2003; 47(1):39-41.

10. Rugg-Gunn A, Nunn J. Nutrition, diet and oral health. Oxford: Oxford University Press; 1999.

11. Campbell M, DeVellis B, Strecher V. Improving a dietary behaviour: The effectiveness of tailored messages in primary care settings. Am J Publ Health 1994; 84: 783-7.

12. Selwitz RH, Ismail A, Pitts NB. Dental caries. Lancet 2007; 369: 51-9.

13. Reisine S, Douglas JM. Psychosocial and behavioral issues in early childhood acries. Comm Dent Oral Epidemiol 1998; 26: 32-44.

14. Vargas CM, Crall JJ, Schneider DA. Sociodemographic distribution of pediatric dental caries: NHANES III, 1998-1994. J Am Dent Assoc 1998; 1229-38.

15. Fontana M, Zero DT. Assessing patients caries risk. J Am Dent Assoc 2006; 137(9): 1231-9.

16. Mobley CC. Nutrition and dental caries. Dent Clin North Am 2003; 47: 319-36.

17. Page RC. The pathobiology of periodontal diseases may affect systemic diseases: Inversion of a paradigm. Ann Periodontol 1998; 3(1):108-20.

18. Pihlstrom BL. Periodontal risk assesment, diagnosis and treatment planning. Periodontol 2000 2001;25:37-58.

19. Boyd LD, Lampoi KJ. Importance of nutrition for optimum health of the periodontium. J Contemp Dent Pract 2001; 2 (2).

20. Moore JR, Gillbe GV. Principles of oral surgery. 3 rd Ed. Manchester: Manchester University Press; 1981.

21. Fearon KCH, Luff R. The nutritional management of surgical patients: enhanced recovery after surgery. Proceeding of the Nutrition Society; Cambridge: Cambridge University Press 2001 (60): Proceeding of the Nutrition Society 2003; 62:807-11.

22. Sprod A, Anderson R, Treasure E. Effective oral health promotion: Literature Review. Wales: Cardiff Health Promotion; 1996.

23. Moynihan PJ, Petersen PE. Diet, nutrition and the prevention of dental diseases. Publ Health Nutr 2004;7:201-26.

24. Marshall T, Levy SM, Brofitt B, Warren JJ. Dental caries and beverage consumption in young children. Pediatr 2003;112:184-91.

25. Burt B, Pai S. Sugar consumption and caries risk: A systematic review. J Dent Educ 2001; 65:101723. 